\title{
Myeloid Sarcoma: A Masquerade
}

\author{
Shweta Rathi, Poonam Panjwani, Anuradha Ananthamurthy, Pritilata Rout \\ Department of Pathology, St. John's Medical College, Sarjapur Road, Kormangala, Bangalore, India.
}

\section{Corresponding Author:}

Dr Shweta Rathi

Email: drshwetamantri12@gmail.com

This is an Open Access article distributed under the terms of the Creative Commons Attribution License (creativecommons.org/ licenses/by/3.0).

Received : September 6, 2020

Accepted : October 27, 2020

Published : November 30, 2020

\begin{abstract}
Background: Myeloid sarcoma (MS) may occur de novo, precede or coincide with acute myeloid leukemia (AML) but its presentation as the initial manifestation is rare. Case Report: We present a series of six cases of myeloid sarcoma in an age group ranging from 15 to 62 years, involving paraspinal area, lymph node, ileum and appendix. Three cases had a prior diagnosis of AML and in the rest, a diagnosis of myeloid sarcoma preceded further investigations which did not reveal any other site of involvement. Conclusion: The diagnosis of myeloid sarcoma is important especially in patients who do not have associated hematologic abnormalities at presentation. Immunohistochemistry is an invaluable tool that assists in arriving at a correct diagnosis.
\end{abstract}

Keywords: Acute Myeloid Leukemia, Immunohistochemistry, Lymph Nodes, Myeloid Sarcoma, Soft Tissue Neoplasms.

\section{Introduction}

Myeloid sarcoma (MS) is an extramedullary tumor of myeloblasts or immature myeloid cells. MS was first described by Burns in 1811, later also termed chloroma by King because of its green appearance on gross morphology owing to myeloperoxidase enzymes in the myeloblasts $[1,2]$. The commonly involved sites are skin, lymph nodes, gastrointestinal tract, bone, soft tissue and testis $[3,4]$ while other rare sites include heart, spinal cord and liver [5,6-9]. The diagnosis of myeloid sarcoma can be challenging due to its varied clinical presentations and overlap with other lymphoid malignancies with respect to cytomorphology, cytochemistry and cytogenetic findings. Immunohistochemistry can assist in the proper diagnosis and thereby guide the treatment protocols.

\section{Case Report}

The present study at our institute included 6 cases over a period of six years. A review of case records, histopathology and immunohistochemistry was done correlating with the available bone marrow aspirates. Immunohistochemistry was done with the polymer technology method using prediluted primary antibodies from Dakoand Envision Secondary kit (Dako; Carpinteria, CA). Follow up data of the patients were retrieved. Of the six cases included in the study, the male to female ratio was $5: 1$. The age ranged from 15 to 62 years (median age $=33$ ). The location of the lesion at presentation in these cases was paraspinal area, lymph node, ileum and appendix. The commonest presenting symptom was localized swelling in accordance with the site. Three cases had a prior diagnosis of AML and in the other three, a diagnosis of myeloid sarcoma lead to further investigations which did not reveal any other sites of involvement. In five of these cases, immunohistochemistry was performed for confirmation. The details of the cases are summarized in Table 1.

All cases showed diffuse infiltration of mononuclear cells effacing the architecture of the underlying tissue. The cells showed scant 
Table 1: Details of all the 6 cases of myeloid sarcoma.

\begin{tabular}{|l|l|l|l|l|l|l|l|}
\hline $\begin{array}{l}\text { Case } \\
\text { No. }\end{array}$ & $\begin{array}{l}\text { Age } \\
\text { (In Yrs) }\end{array}$ & Sex & Site & BM/PS findings & Positive markers & Negative markers & Final diagnosis \\
\hline 1 & 15 & M & $\begin{array}{l}\text { Paraspinal } \\
\text { region }\end{array}$ & $\begin{array}{l}\text { No prior diagnosis } \\
\text { of AML at } \\
\text { presentation }\end{array}$ & $\begin{array}{l}\text { MPO, LCA, CD99, } \\
\text { Vimentin }\end{array}$ & $\begin{array}{l}\text { CK, Myogenin, } \\
\text { CD79a, CD138, } \\
\text { ALK, CD20, CD3, } \\
\text { CD5, CD30, TdT }\end{array}$ & Myeloid sarcoma \\
\hline 2 & 16 & F & Appendix & $\begin{array}{l}\text { Diagnosed case of } \\
\text { AML }\end{array}$ & MPO & - & Myeloid sarcoma \\
\hline 3 & 24 & F & $\begin{array}{l}\text { Cervical } \\
\text { LN }\end{array}$ & $\begin{array}{l}\text { Diagnosed case of } \\
\text { AML }\end{array}$ & $\begin{array}{l}\text { MPO, LCA, CD31, } \\
\text { CD61 }\end{array}$ & CD20, CD3, CD34 & $\begin{array}{l}\text { Myeloid } \\
\text { sarcoma with } \\
\text { megakaryoblastic } \\
\text { differentiation }\end{array}$ \\
\hline 4 & 38 & F & $\begin{array}{l}\text { Cervical } \\
\text { LN }\end{array}$ & $\begin{array}{l}\text { No prior diagnosis } \\
\text { of AML at } \\
\text { presentation }\end{array}$ & $\begin{array}{l}\text { MPO, CD117, } \\
\text { CD34, Bcl-2, TdT, } \\
\text { CD68 }\end{array}$ & $\begin{array}{l}\text { CD20, CD79a, CD3, } \\
\text { CD5, CD10, CD23. }\end{array}$ & Myeloid sarcoma \\
\hline 5 & 45 & F & Ileum & $\begin{array}{l}\text { No prior diagnosis } \\
\text { of AML at } \\
\text { presentation }\end{array}$ & $\begin{array}{l}\text { MPO, LCA, CD117, } \\
\text { Td, CD34, Bc1-2 }\end{array}$ & $\begin{array}{l}\text { CD20, CD5, CD56, } \\
\text { Cyclin D1, CD10, } \\
\text { CD23, ALK, CK, } \\
\text { Cd1a }\end{array}$ & Myeloid sarcoma \\
\hline 6 & 62 & F & $\begin{array}{l}\text { Cervical } \\
\text { LN }\end{array}$ & $\begin{array}{l}\text { Diagnosed case of } \\
\text { AML }\end{array}$ & $\begin{array}{l}\text { MPO, CD117, CD3, } \\
\text { CD5, CD8, CD4, } \\
\text { CD7 }\end{array}$ & $\begin{array}{l}\text { CD20, CD15, PAX5, } \\
\text { CD23, CD10 }\end{array}$ & Myeloid sarcoma \\
\hline
\end{tabular}

cytoplasm, round nuclei, fine nuclear chromatin and prominent nucleoli. The IHC panel included LCA, MPO, CD68, CD117, Ki67, CD3, CD20 and TdT. All the cases were positive for MPO and two cases were positive for CD68.

\section{Discussion}

The differential diagnosis of MS is often a clinical challenge. The incidence of myeloid sarcoma in patients without leukemia (primary myeloid sarcoma) is 2 per million in adults [10]. In adults, roughly one third of myeloid sarcomas present with concurrent myeloid neoplasm and one third have a history of myeloid neoplasms. The secondary forms of myeloid sarcoma occur in 1-9\% of patients with AML $[11,12]$. Though MS may involve any organ or body system, the symptoms are substantially related with the anatomic location that is involved, lymph nodes being most frequent site in our series.

The diagnosis of myeloid sarcoma is important in patients who do not have associated hematologic abnormalities at presentation. Only leukemic infiltrates that form tumor are called myeloid sarcomas. Mature or immature types of MS can be confused with Hodgkin lymphoma, T-cell lymphomas, extramedullary hematopoiesis (myeloid metaplasia) or infectious processes. Additionally, blastic types of MS can be confused with non-Hodgkin lymphoma (diffuse large B-cell lymphoma, lymphoblastic lymphoma, blastoid mantle cell lymphoma), lymphoblastic lymphoma, poorly differentiated carcinoma, or melanoma [13]. A high degree of suspicion and immunohistochemistry are necessary to arrive at a diagnosis.

Immunophenotyping of MS includes variable positivity for $\mathrm{MPO}, \mathrm{CD} 68, \mathrm{CD} 34$, CD117, TdT. Immunohistochemistry for MPO, which is commonly expressed by cells of the myeloid lineage was positive in $100 \%$ of our cases. Also, CD68, which is more common in cells of monocytic lineage, was expressed in $40 \%$ of the cases. Histopathology and cytomorphology are less informative than cytogenetics, cytochemistry 
and immunophenotyping. Audouin et al. noted that the infiltrate in MS can be massive, obscuring and destroying normal tissue, with perivascular infiltration being a common histopathologic finding [14]. Cytomorphologic classification of tumors by degree of differentiation does not change the prognosis of the patient and is clinically insignificant $[15,16]$.

The role of cytogenetics in the diagnosis of MS is becoming increasingly important. Pileri et al. [17] found that monosomy 7 (10.8\%), trisomy $8(10.4 \%)$, and mixed lineage leukemia splitting $(8.5 \%)$ were the most frequently encountered abnormalities. The $t(8 ; 21)(p 22 ; q 22)$ translocation, previously thought to be the most common cytogenetic abnormality, is now known to be more common in childhood or in MS involving the orbit $[18,19]$. Overall, the recorded incidence of chromosomal aberrations appears to be in line with that seen in adult AML [18]. The importance of arriving at a diagnosis of MS cannot be overemphasized, as early diagnosis and appropriate treatment strategies need to be implemented before the disease progresses to AML, thereby ensuring better prognosis [20].

\section{Conclusion}

Myeloid sarcoma poses a diagnostic dilemma due to its variable clinical attributes. This diagnosis should be kept as a differential for atypical cellular infiltrate at an extramedullary site. Present study highlights the rare incidence and importance of early detection for prompt treatment to prevent or delay the progress to the leukemia stage.

Contributors: SR: Manuscript writing, literature review and histopathology; PP, AA: manuscript editing, references and histopathology. PR: critical inputs into the manuscript. SR will act as a study guarantor. All authors approved the final version of this manuscript and are responsible for all aspects of the study.

Funding: None; Competing interests: None stated.

\section{References}

1. Burns A. Observation of surgical anatomy. Head and Neck. Royce, London, UK 1811;364.
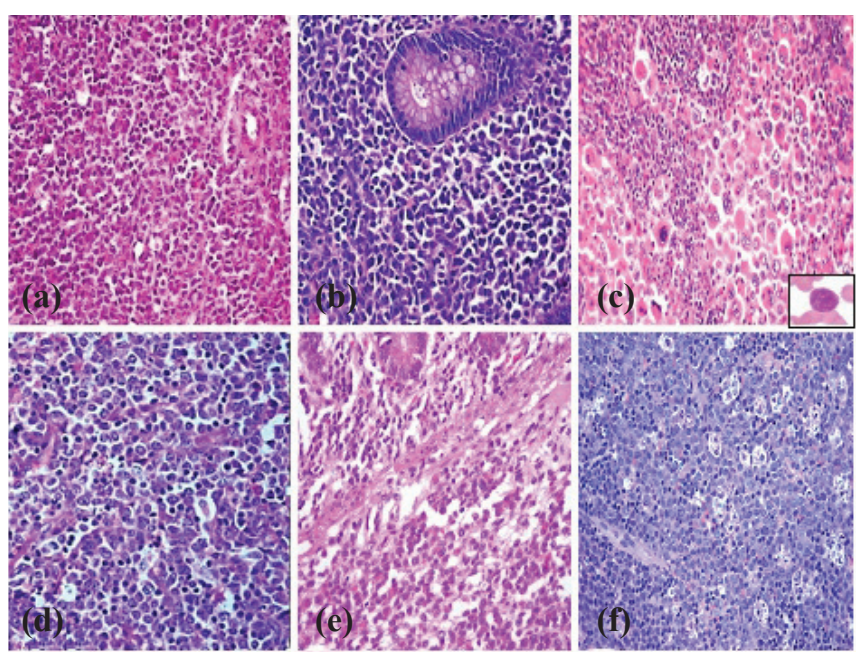

Fig.1: Atypical lymphoid cells of myeloid sarcoma (a) paraspinal region; (b) appendix; (c) cervical lymph node: Atypical lymphoid cells with megakaryoblastic differentiation (inset); (d) cervical lymph node; (e) ileum; (f) cervical lymph node.

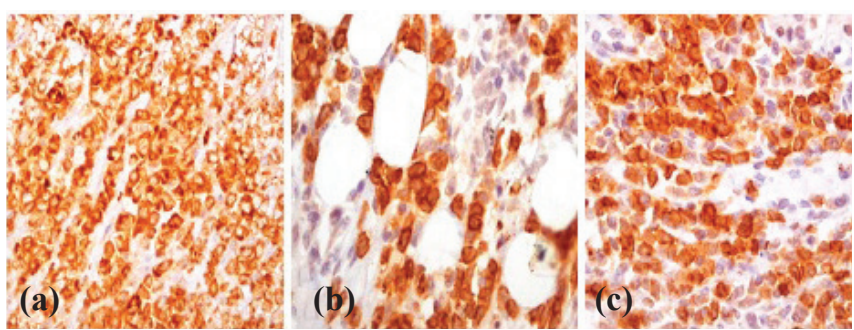

Fig.2: The tumor cells show diffuse strong positivity for (a) myeloperoxidase (MPO) immunostain (× 400); (b) CD117 (×400); (c) CD34 (×400).

2. King A. A case of chloroma. The Monthly Journal of Medicine. 1853;17:97.

3. Falini B, Lenze D, Hasserjian R, Coupland S, Jaehne D, Soupir C, et al. Cytoplasmic mutated nucleophosmin (NPM) defines the molecular status of a significant fraction of myeloid sarcomas. Leukemia. 2007;21:15661570 .

4. Pileri SA, Ascani S, Cox MC, Campidelli C, Bacci F, Picciol M, et al. Myeloid sarcoma: clinico-pathologic, phenotypic and cytogenetic analysis of 92 adult patients. Leukemia. 2007;21:340-350.

5. Pileri SA, Orazi A, Falini B. Myeloid sarcoma. In: Swerdlow SH, Campo E, Harris NL, Jaffe ES, Pileri SA, Stein H, Thiele J, Vardiman JW (eds). WHO classification of tumors of haematopoietic and lymphoid tissues. Lyon: IARC Press 2008; $4^{\text {th }}$ edn:140-141.

6. Paydas S, Zorludemir S, Ergin M. Granulocytic sarcoma: 32 cases and review of the literature. Leuk Lymphoma 2006;47:2527-2541. 
7. Choi EK, Ha HK, Park SH, et al. Granulocytic sarcoma of bowel: CT findings. Radiology. 2007; 243:752-759.

8. Kitagawa Y, Sameshima Y, Shiozaki H, Ogawa $\mathrm{S}$, Masuda A, Mori S, et al. Isolated granulocytic sarcoma of the small intestine successfully treated with chemotherapy and bone marrow transplantation. Int $\mathrm{J}$ Hematol. 2008;87:410-413.

9. Antic D, Vuckovic M, Elezovic I. Right atrial myeloid sarcoma causing superior vena cava syndrome. Br J Haematol. 2008;141:134.

10. Yuan Y, Qin X, Yan S, Wang W, Sun Y, Zhang M. Nonleukemic myeloid sarcoma involving the vulva, vagina, and cervix: a case report and literature review. Onco Targets Ther. 2015;8:3707-3713.

11. Tsimberidou AM, Kantarjian HM, Estey E, Cortes JE, Verstovsek S, Faderl S, et al. Outcome in patients with nonleukemic granulocytic sarcoma treated with chemotherapy with or without radiotherapy. Leukemia. 2003; 17:1100-1103.

12. Zekry N, Klooster MJ, Raghavan R, Wang J. A 7-year-old child with a history of acute myeloid leukemia presenting with multiple gastrointestinal polyps. Extramedullary myeloid sarcoma. Archives of Pathology \& Laboratory Medicine. 2006;130:e3-e4.

13. Suh YK, Shin HJ. Fine-needle aspiration biopsy of granulocytic sarcoma a clinicopathologic study of 27 cases. Cancer. 2000;90:364-372.
14. Audouin J, Comperat E, Le Tourneau A, Camilleri-Broet $\mathrm{S}$, Adida C, Molina T, et al. Myeloid sarcoma: clinical and morphological criteria useful for diagnoses. Int $\mathrm{J}$ Surg Pathol. 2003;11:271-282.

15. Traweek S, Arber DA, Rappaport H, Brynes RK. Extramedullary myeloid tumors. An immunohistochemical and morphologic study of 28 cases. Am J Surg Pathol. 1993;17:1011-1019.

16. Menasce LP, Banerjee SS, Beckett E, Harris M. Extramedullary myeloid tumor (granulocytic sarcoma) is often misdiagnosed: a study of 26 cases. Histopathology. 1999;23:391-398.

17. Pileri SA, Ascani S, Cox MC, Campidelli C, Bacci F, Piccioli M, et al. Myeloid sarcoma: clinico-pathologic, phenotypic and cytogenetic analysis of 92 adult patients. Leukemia. 2007;21:340-350.

18. Tallman MS, Hakimian D, Shaw JM, Lissner GS, Russell EJ, Variakojis D. Granulocytic sarcoma is associated with 8;21 translocation in AML. J Clin Oncol. 1993;11:690-697.

19. Byrd JC, Edenfield WJ, Shields DJ, Dawson NA. Extramedullary myeloid cell tumors in acute nonlymphocytic leukemia: a clinical review. J Clin Onco. 11995;13:1800-1816.

20. Huang XL, Tao J, Li JZ, Chen XL, Chen JN, Shao CK, et al. Gastric myeloid sarcoma without acute myeloblastic leukemia, World J. Gastroenterol. 2015;21:2242-2248. 